Iran Journal of Nursing (IJN)

Vol 32, No. 117, Apr 2019: 58- 68

\title{
The Prevalence, Barriers to Medication Error Reports, and Perceptions of Nurses toward the Causes of Medication Errors in the Hospitals Affiliated to North Khorasan University of Medical Sciences, Iran
}

\author{
Maryam Ghorbanzadeh ${ }^{1}$, Sepideh Gholami ${ }^{2}$, Azade Sarani ${ }^{3}$, Faezeh Badeli ${ }^{4}$, \\ *Fatemeh Nasimi ${ }^{5}$
}

\begin{abstract}
Background \& Aims: Medication errors are major healthcare concerns across the world, which cause mortality and physical and psychological complications in patients, their families, and the community every year. Considering the key role of nurses in direct patient care, the present study aimed to investigate the prevalence, barriers to medication error reports, and influential factors in medication errors in the viewpoint of nurses.

Materials \& Methods: This cross-sectional, descriptive-analytical study was conducted on 140 nurses employed in the teaching hospitals in Bojnurd, Iran in 2017. Data were collected using a questionnaire consisting of four sections, including the demographic data, evaluation of the type of medication errors, cause of not reporting medication errors, and their influential factors. Data analysis was performed in SPSS version 16.

Results: The most important causes of medication errors included ward-related factors (3.40 \pm 0.69$)$, factors related to nursing management (3.31 \pm 0.91$)$, and nurse-related factors $(3.16 \pm 0.78)$. In addition, the most important cause of not reporting medication errors was the process of error reports. Significant associations were also observed between the demographic characteristics of the nurses, medication errors, medication protocols, nurse-related factors, ward-related factors, fear of the consequences of error reporting, factors related to the error report process, and fear of the managerial factors.

Conclusion: Considering that most medication errors were correlated with ward-related and managerial factors, nursing managers must focus on correcting the influential processes in medication errors and their reporting, simultaneously seeking strategies to control and mitigate these errors.
\end{abstract}

Keywords: Medication Errors, Nurses, Reporting Systems

\section{Conflict of Interest: No}

How to Cite: Ghorbanzadeh M, Gholami S, Sarani A, Badeli F, Nasimi F. The Prevalence, Barriers to Medication Error Reports, and Perceptions of Nurses toward the Causes of Medication Errors in the Hospitals Affiliated to North Khorasan University of Medical Sciences, Iran. Iran Journal of Nursing. 2019; 32(117):5868.

Received: 14 Jan 2019

Accepted: 17 Apr 2019

\footnotetext{
1. Lecturer, Department of Anesthesiology, School of Nursing and Midwifery, North Khorasan University of Medical Sciences, Bojnurd, Iran

2. Lecturer, Department of Operation Room, School of Nursing and Midwifery, North Khorasan University of Medical Sciences, Bojnurd, Iran

3 . Lecturer, Department of Midwifery, School of Medicine, Islamic Azad University, Zahedan Branch, Zahedan, Iran

${ }^{4}$. BS in Nursing, Student Research Committee, School of Nursing and Midwifery, North Khorasan University of Medical Sciences, Bojnurd, Iran

5. Lecturer, Department of Nursing, School of Nursing and Midwifery, Islamic Azad University, Kazerun Branch, Kazeron, Iran (*Corresponding author)

Tel: 09171259335)

Email: nasimif@yahoo.com
} 


\title{
شيوع، موانع كزارشدهى و عوامل مؤثر بر بروز خطاهاى دارويى از ديدكاه برستاران در

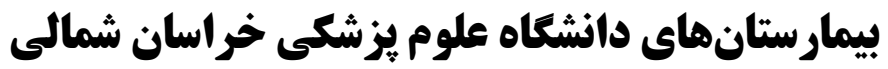

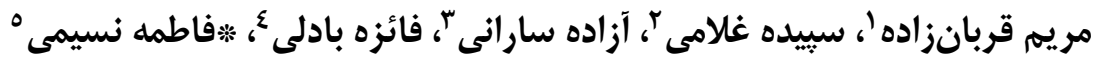

\begin{abstract}
جكيده

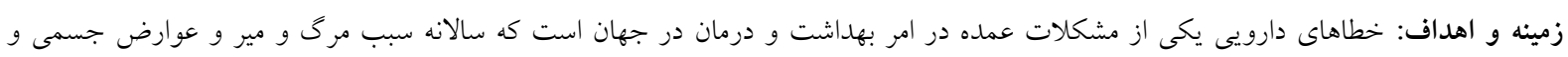

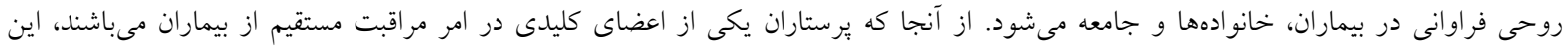

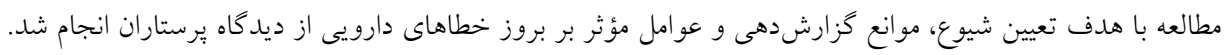

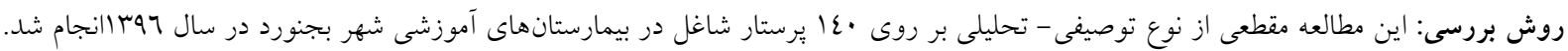

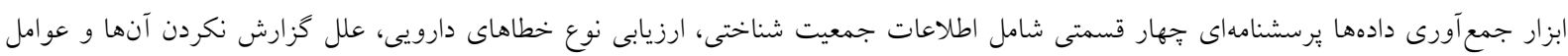

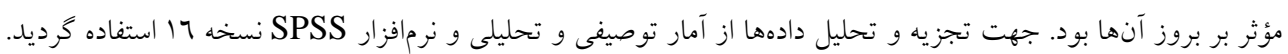

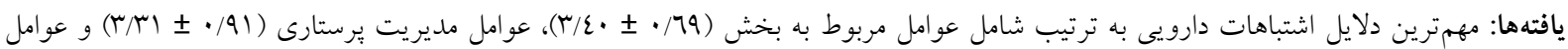

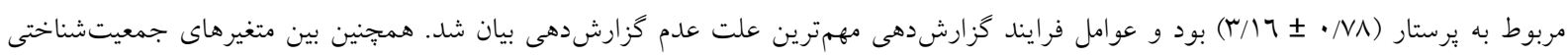

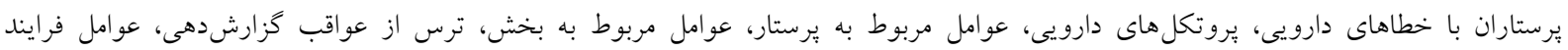

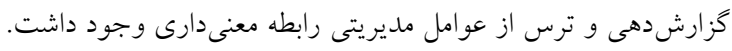

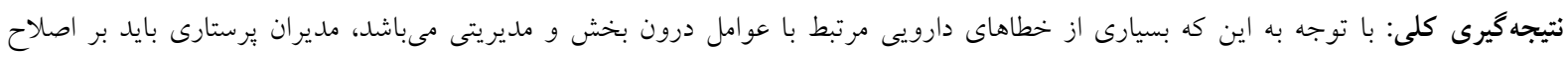

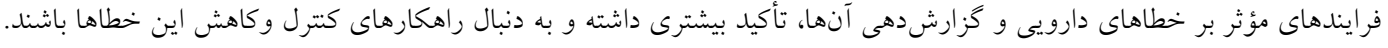

كليد وازٔها: خطاهاى دارويى، يرستاران، سيستمهاى كزارشدهى

تعارض منافع: ندارد

تاريخ دريافت: ع ع

تاريخ بذيرش: MN/1/TA

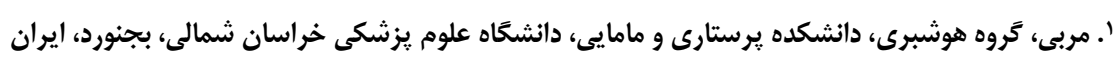

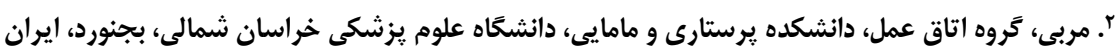

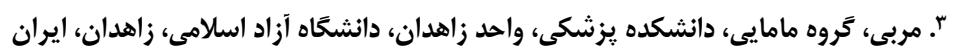

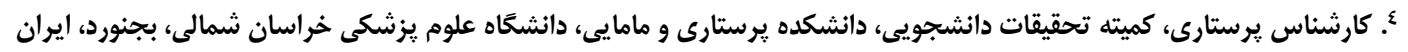

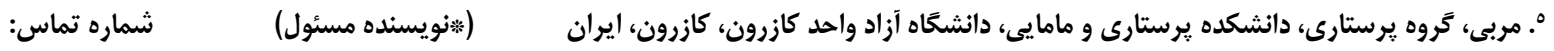


كه سالانه يك ميليون اشتباه دارويى رخ مىدهد (9). مطالعهاى در انخلستان نشان داد كه ميزان بروز اشتباهات

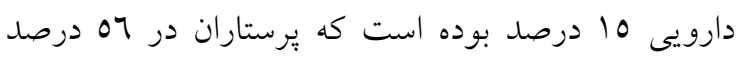

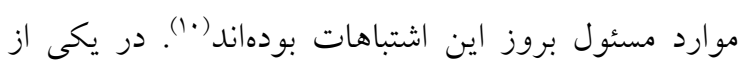

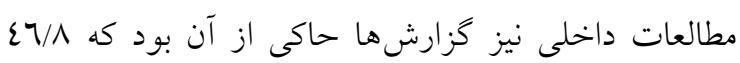

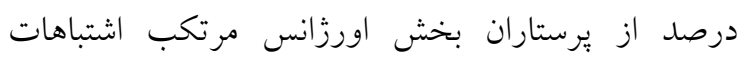

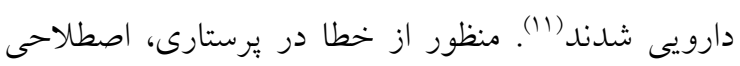

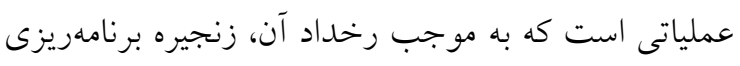

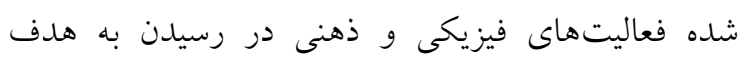

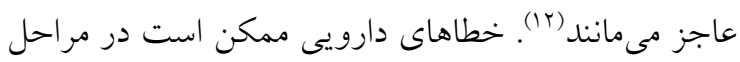

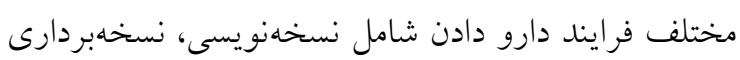

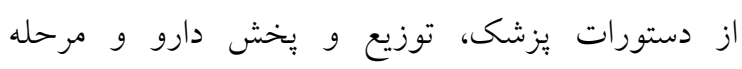

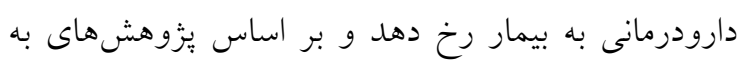

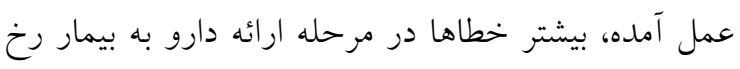

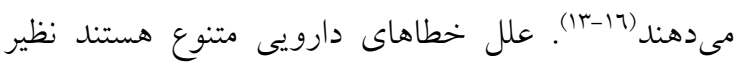

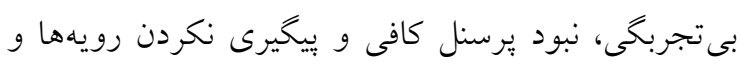

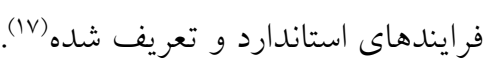
عمدهترين علل خطاهاى دارويى را بار كارى Harding

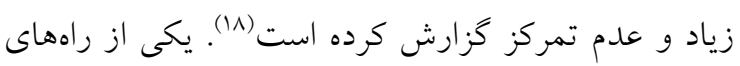

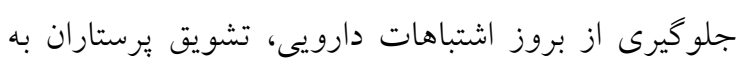

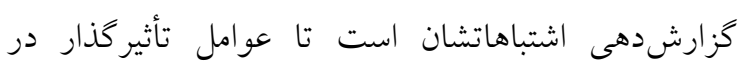

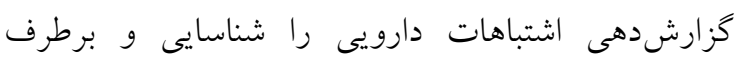

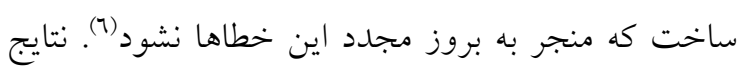

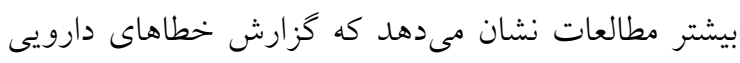

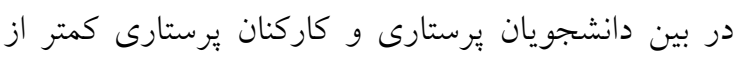
ميزان واقعى است(7). در حالى كه تحقيقات نشان دادهاند ميزان بروز خطاهاى دارويى در آن ها بالا است (19).

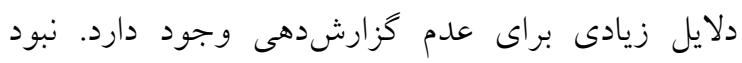

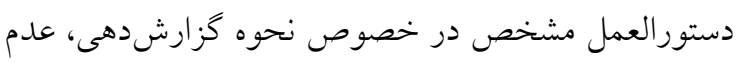

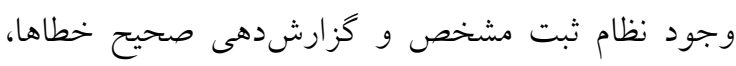
ترس، فرايند گزارشدهى مشكل، موانع مديريتى و موانع

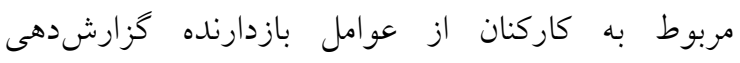

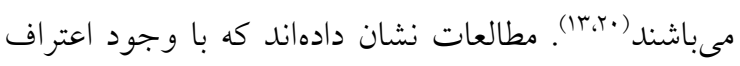

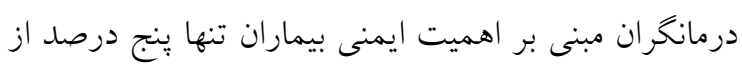

\section{مقدمه}

خطاهاى بزشكى يكى از مشكلات عمده در امر بهداشت

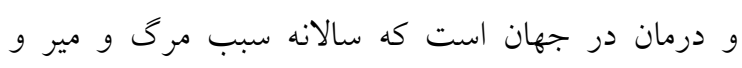

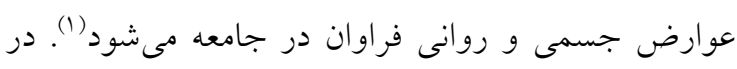

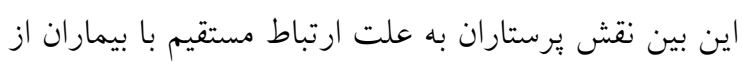

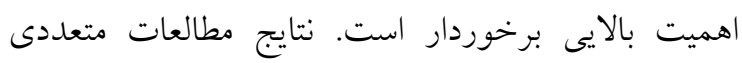

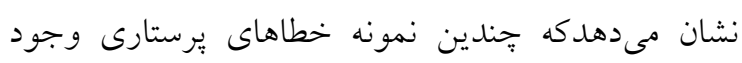

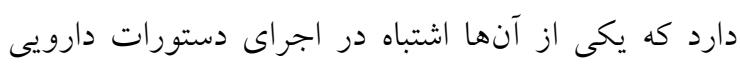

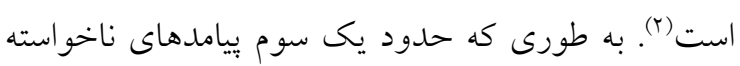

دارويى به دليل اشتباهات دارويى گزارش شده است (r).

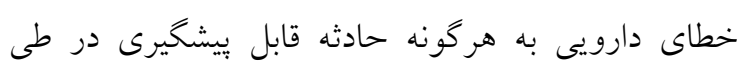

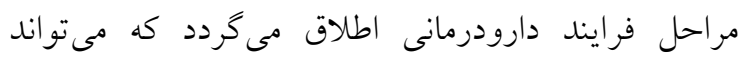

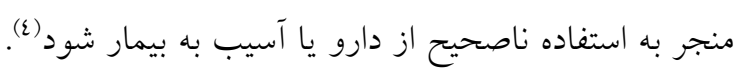

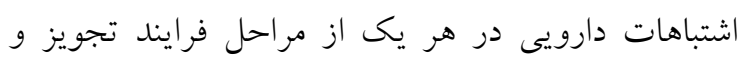

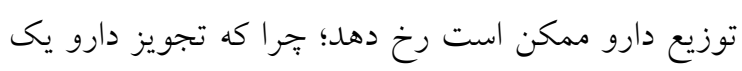

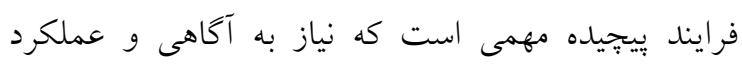

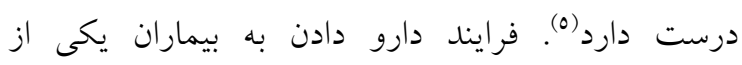

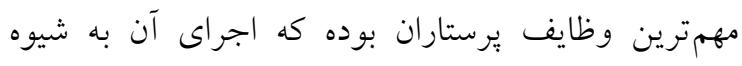
صحيح نقش بسزايى در امر ايمنى بيمار ايفاء مى كند (7).

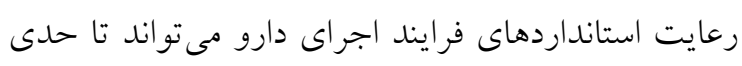
منجر به كاهش ميزان خطاهاى دارويى شود اما در بيشتر

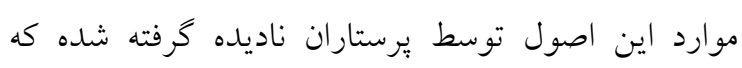

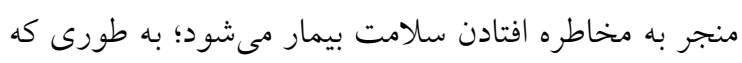

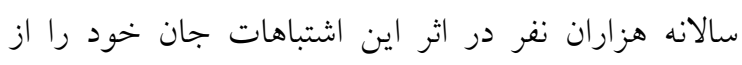

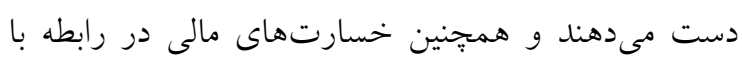

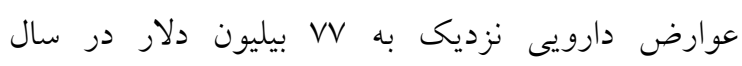

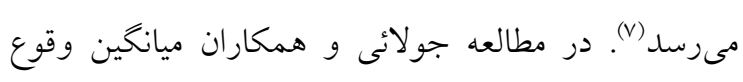

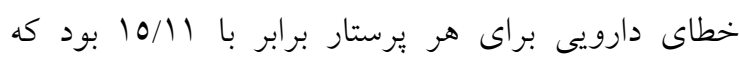

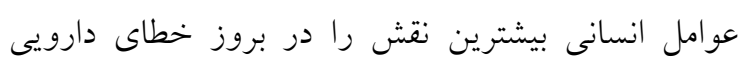
داشتند (^) در يك مطالعه كَذشتهنح از 97 مرك ناشى از اشتباهات

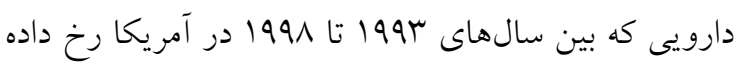

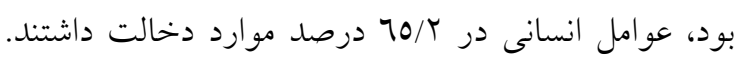

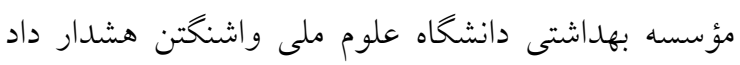


روش يزوهش به مشاركت كنند كان كسب رضايت آكَاهانه

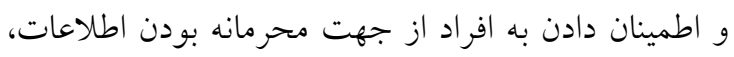

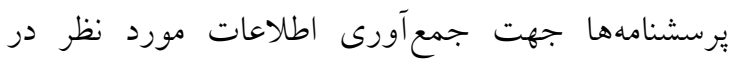
اختيار برستاران واجد شر ايط در شيفتهاى مختلف كارى از هر سه بيمارستان قرار داده شد. يرستاران در شيفتهاى

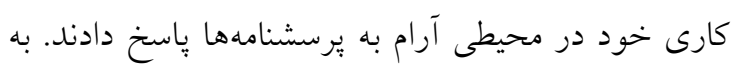

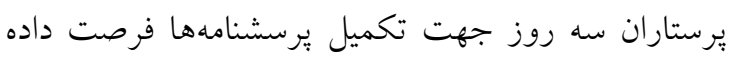

ابزار جمعآورى دادهها يُرسشنامهاى جهار قسمتى بود كه از مطالعات مشابه كذشته استخراج شده بود. قسمت اول مربوط به اطلاعات جمعيت شناختى و شغلى است كه حاوى سئو الاتى مانند جنسيت، سن، سطح تحصيلات،

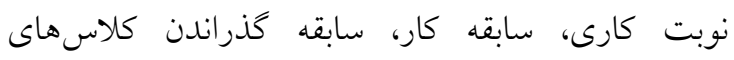

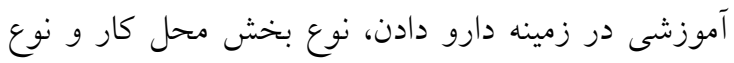

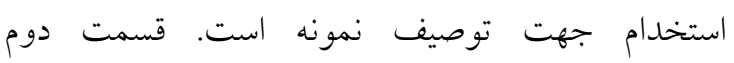

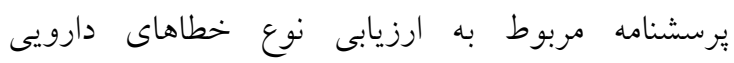
(9اكويه) است كه در طى سه ماه كذشته براى يرستاران

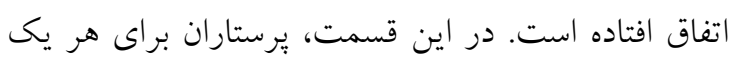

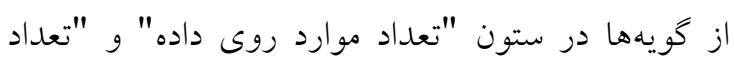

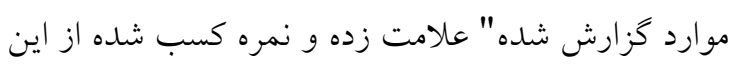

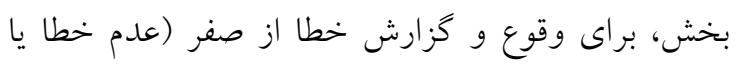

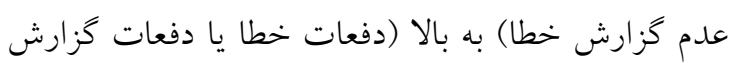
خطا) است (rr) (r)

قسمت سوم يرسشنامه مربوط به عوامل مؤثر بر بروز

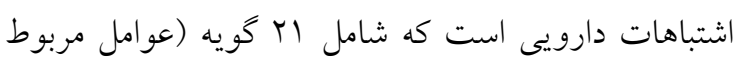

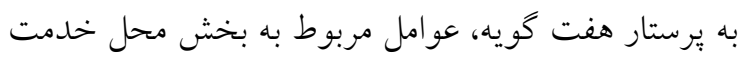

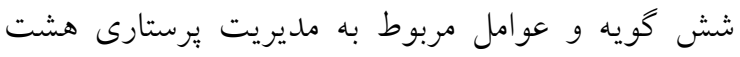

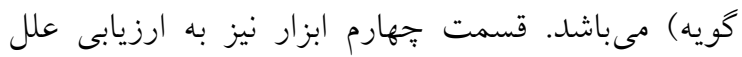

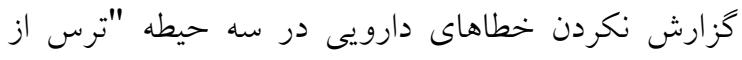

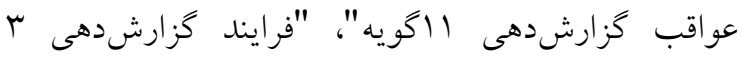
كويه" و "عوامل مديريتى 0 كويه" شامل 19 كويه

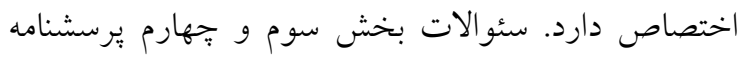
بر اساس مقياس ينج نمرهاى ليكرت از كاملاً موافق (نمره

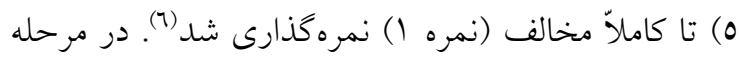

خطاهاى بالقوه تهايدكننده زندگى گزارش مىشود. در

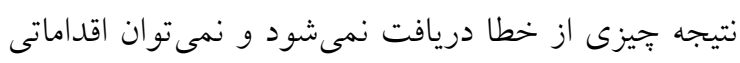

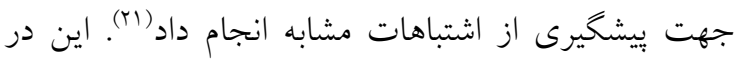

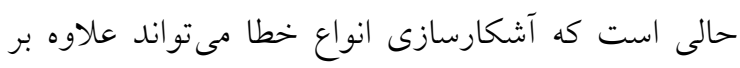

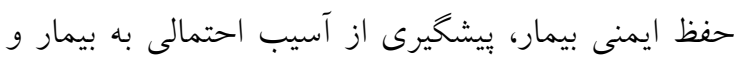

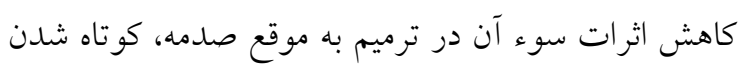
مدت بسترى بيمار، كاهش هزينهاى مالى سازمان و بيمار

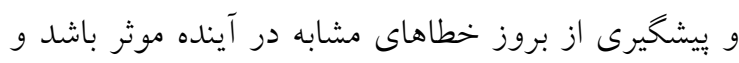

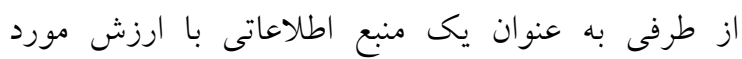

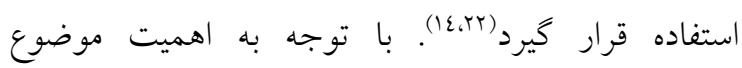
خطاهاى دارويى و اثرات مخربى كه رعايت نكردن اصول استاندارد در فرايند دارو درمانى بر روى بيماران به جا

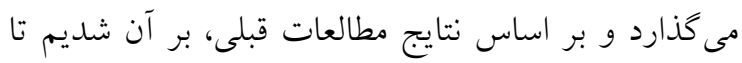

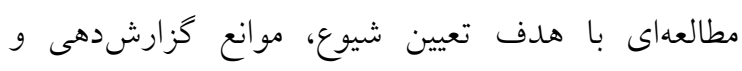
عوامل مؤثر بر بروز خطاهاى دارويى از ديدكاه برستاران

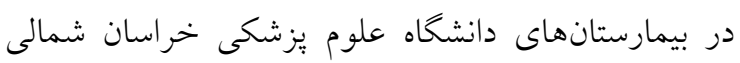

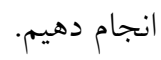

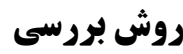

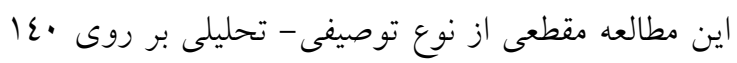

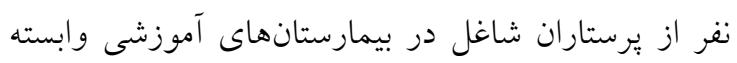

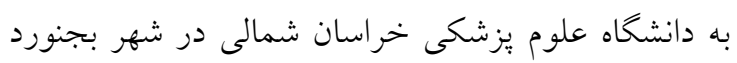
در سال 971 انجام شد. افراد به صورت سرشمارى وارد مطالعه شدند. يزوهشكر يس از اخذ تأييد كميته اخلاق

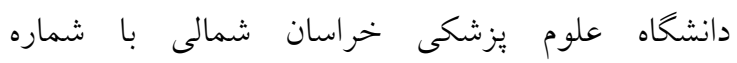

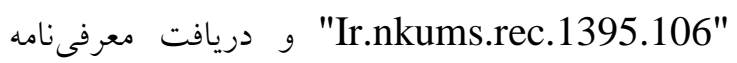
رسمى و ارائه آن به مسئولين سه بيمارستان آموزشى شهر بجنورد، تحقيق را شروع كرد. معيارهاى ورود به مطالعه

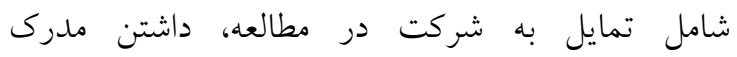

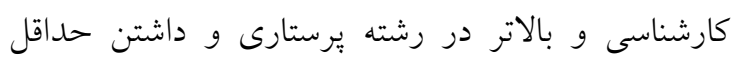

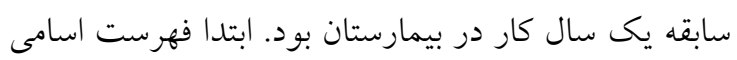

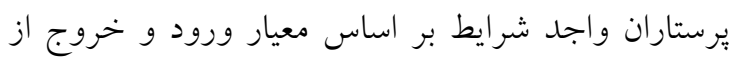

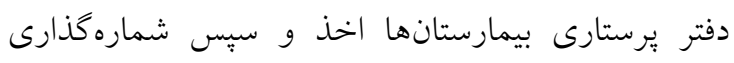

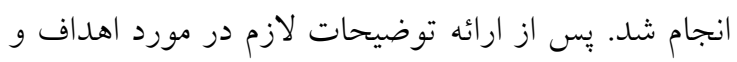


خير)، از آزمونهاى همبستخى اسبيرمن و بِيرسون استفاده كرديد.

\section{يافتهها}

نتايج تحقيق نشان داد كه ميانخين و انحراف معيار سنى يرستاران شركت كننده در مطالعه،

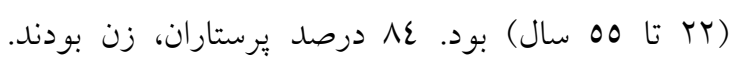

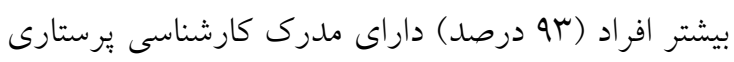

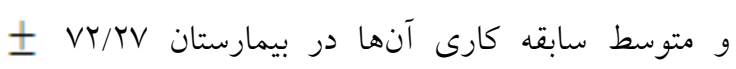
N NT/rV 

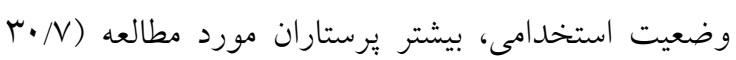

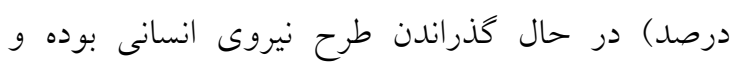

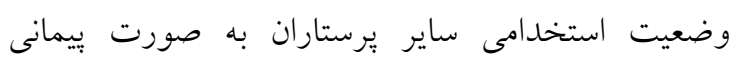

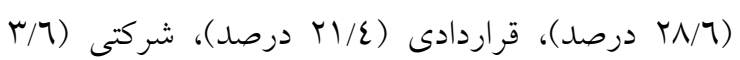
درصد) و رسمى (10 درصد) بود. همجنين بيشتر افراد

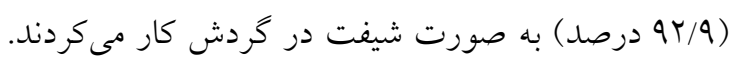

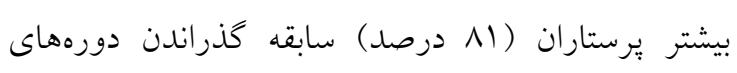

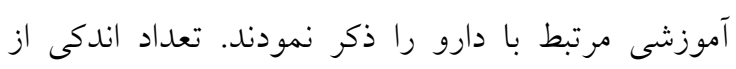
ير بتاران (0 درصد)، دارو مصرف مى كردند.

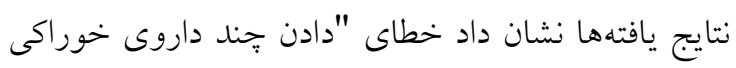

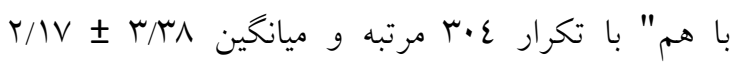
بيشترين ميزان خطا و خطاى "تزريق داروى وريدى بـ به ونه

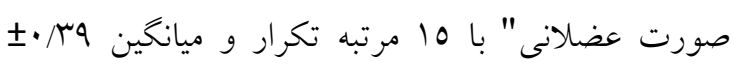
• 1/، كمترين ميزان خطا را در طول سه ماه كذشته شامل

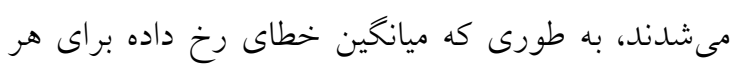

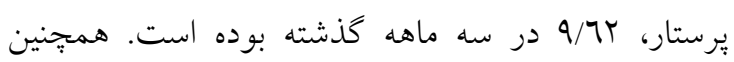

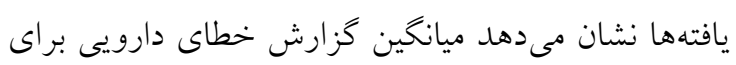

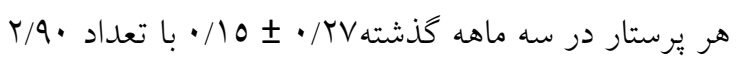

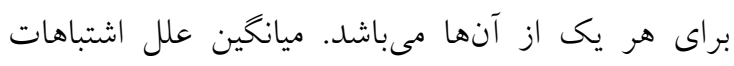
دارويى در سه حيطه مورد بررسى قرار كرفت. مهمترين

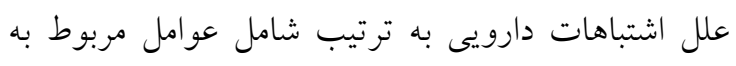

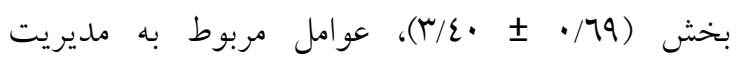

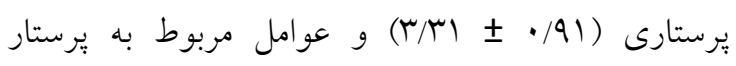

بعد ميانخين نمره هر سئوال و ميانخين نمره هر حيطه محاسبه و سبس ميانخين نمرات در حيطهاى مختلف مئف مقايسه شد. قسمت اول برسشنامه يعنى مشخصات جمعيت شناختى و

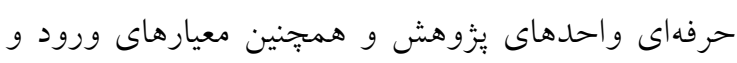

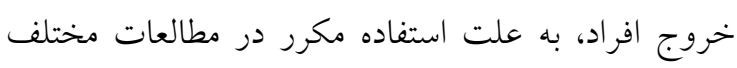

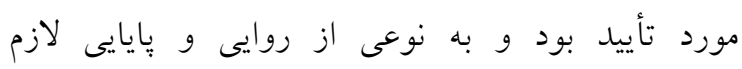

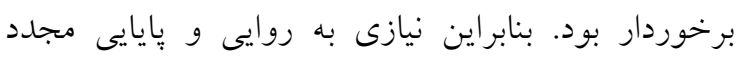
نداشت. براى قسمت دوم يرسشنامه يعنى ارزيابى انواع خطاهاى دارويى از يرسشنامهى جولايى و همكاران استفاده شد.

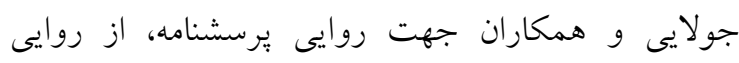

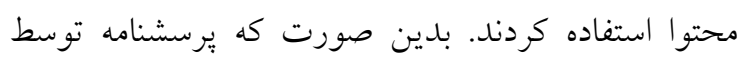

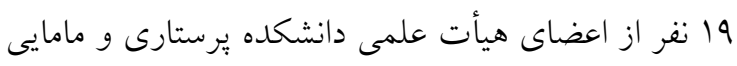

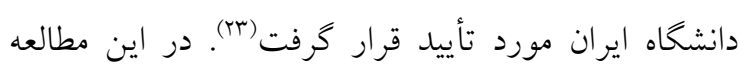
جهت پايايى قسمت دوم يرسشنامه از روش آزمون مجدد

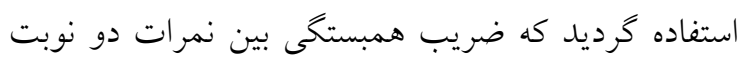

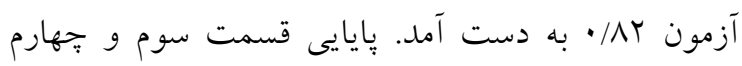
يرسشنامه نيز به روش آلفاى كرونباخ انجام شد. ميزان

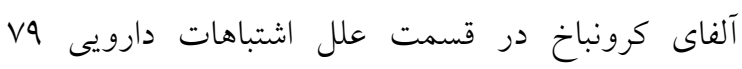
درصد و در قسمت عوامل عدم گزارشدهى اشتباهات دارويى Vo درصد بود. هم:جنين طبق مطالعات كذشتشه

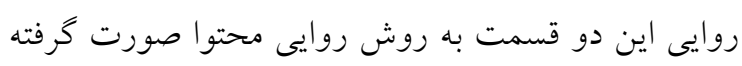

است (7).

دادهها با استفاده از نرم|فزار SPSS نسخه 17 مورد تحليل قرار كرفتند. براى پِاسخ به سئوالات توصيفى مطالعه از

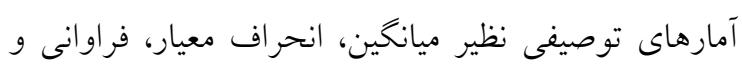
درصد استفاده شد. به منظور بررسى ارتباط علل اشتباهات دارويى، علل عدم كزارشدهى و نوع خطاهاى دارويى و ميزان گزارش آنها با متغيرهاى سن، جنار جنسيت، ميزان

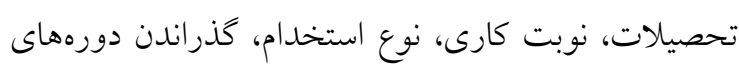

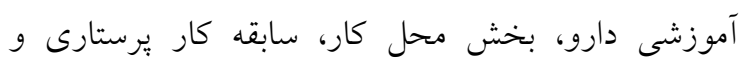
سابقه كار در بخش فعلى، مصرف داروى خاص (بله، 
بدين ترتيب مهمترين علل عدم گزارش دهى از ديدكاه

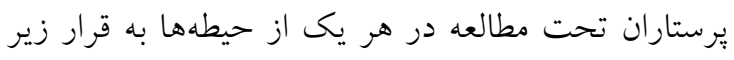

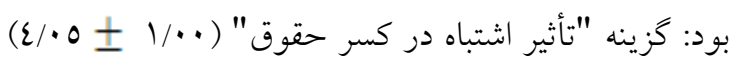
در حيطه ترس از عواقب گزارشدهى، گزينه "تمركز مسئولان تنها به شخص اشتباه كننده بدون توجه به ساير

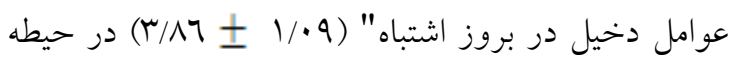

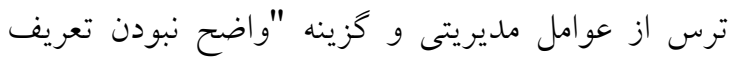

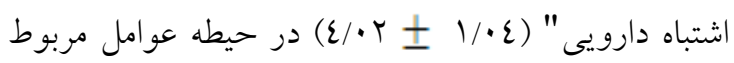
به فرايند گزارشدهى (جدول شماره ).
بود. مهمترين علت خطاى دارويى در (r/17 + • /VN)

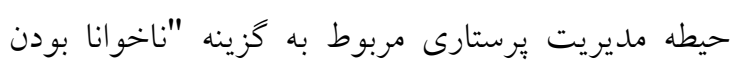

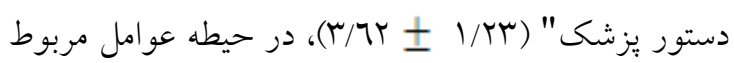

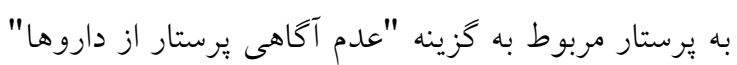

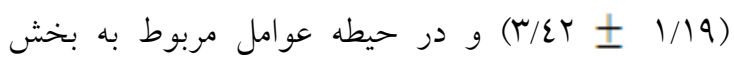

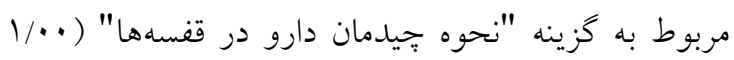
(ع 1 (بود. طبق نتايج مطالعه عوامل مربوط به فردايند كزارشدهى،

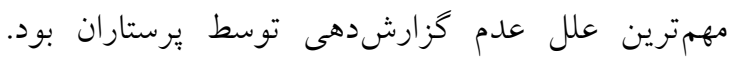

جدول شماره ا: ميانَّين و انحراف معيار علل عدم تَزارشدهى خطاهاى يرستارى از ديدكَاه واحدهاى يزوهش

\begin{tabular}{|c|c|c|}
\hline ميانخين و انحراف معيار نمرات & علل عدم گزارشدهى & عوامل مؤثر \\
\hline$r / T Y \pm 1 / 1$ & تاثير اشتباه در نمره ارزشيابى سالانه & \\
\hline$\varepsilon / \cdot 0 \pm 1 / \cdot$ & تاثير اشتباه در كسر حقوق & \\
\hline$r / r O \pm 1 / \cdot \Lambda$ & سرزنش شدن از طرف مسئولان & \\
\hline$r / \cdot \cdot \pm 1 / \cdot v$ & سرزنش شدن از طرف يزشك معالج بيمار & \\
\hline$r / \wedge \vee \pm 1 / \cdot$ & سرزنش شدن از طرف همكاران & \\
\hline$r / \varepsilon q \pm 1 / r r$ & بروز عوارض جانبى در بيمار & ترس از عواقب ززارشدهى \\
\hline$r / 1 \wedge \pm 1 / 17$ & زدن برجسب بى لياقتى به يرستار & \\
\hline$r / M \pm I / r \varepsilon$ & نحوه برخورد همكاران در بخش (عدم همكارى) & \\
\hline$r / 10 \pm 1 / r 9$ & ايجاد نخرش منفى در بيمار و خانواده وى & \\
\hline$r / \Lambda 1 \pm 1 / r$. & 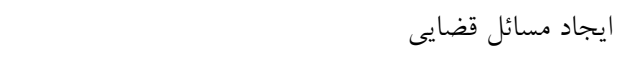 & \\
\hline$r / 1 r \pm 1 / r q$ & انتشار خبر در ساير بخشها و مراكز & \\
\hline$r / 19 \pm \cdot / 7 \varepsilon$ & ميانخين و انحراف معيار كل & \\
\hline$r / N r \pm 1 / \cdot 9$ & اهميت ندادن به گزارشدهى بعضى از اشتباهات دارويى & \\
\hline$\varepsilon / \cdot r \pm 1 / \cdot \varepsilon$ & واضح نبودن تعريف اشتباه دارويى & عوامل مربوط به فرايند \\
\hline$\mu / \mu I \pm 1 / 17$ & فراموش كردن گزارشدهى اشتباه دارويى & كزارشدهى \\
\hline$r / 79 \pm \cdot / 10$ & ميانخين و انحراف معيار كل & \\
\hline$r / 1 \wedge \pm 1 / 19$ & عدبم دريافت بازخورد مثبت از طرف مسئولان برستارى به & \\
\hline$r / r r \pm 1 / 1 r$ & وجود باورهاى غلط در مديران يرستارى & \\
\hline$r / \Lambda 7 \pm 1 / .9$ & 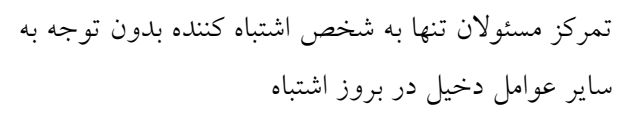 & ترس از عوامل مديريتى \\
\hline$r / 1 \cdot \pm 1 / 1 r$ & نامتناسب بودن واكنش مسئولان با شدت اشتباه دارويى & \\
\hline$r / 1 \varepsilon \pm 1 / \cdot \varepsilon$ & نامتناسب بودن واكنش مسئولان با اهميت اشتباه & \\
\hline$r / \mu \cdot \pm \cdot / \Lambda T$ & ميانخين و انحراف معيار كل & \\
\hline
\end{tabular}


عوامل مربوط به فرايندگزارشدهى و ترس از عوامل

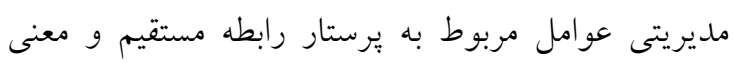
دارى وجود دارد .نتايج آزمون اسبيرمن نشان داد كه بين ميزان تحصيلات با خطاهاى دارويى، يروتكل هاى دارويى بخش و عوامل مربوط به بخش رابطه مستقيم معنىدارى وجود دارد (جدول شماره Y).
نتايج آزمون همبستكى اسبيرمن نشان داد كه بين سابقه كار يرستارى و سابقه كار در بخش فعلى با خطاهاى دارويى و عوامل مربوط به يرستار رابطه معنىدارى وجود دارد. همجنين بين متغير سن با يروتكلهاى دارويى

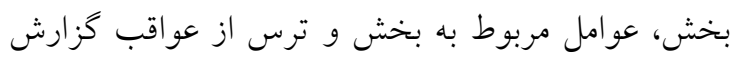
دهى رابطه معكوس و معنىدارى وجود دارد و با تسنى

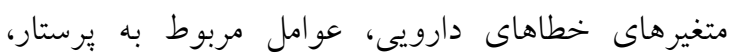

جدول شماره ז: ارتباط بين متغيرهاى كمى جمعيتشناختى با خطاهاى دارويى، موانع تزارشاردهى و عوامل مؤثر بر بروز خطاهاى دارويى

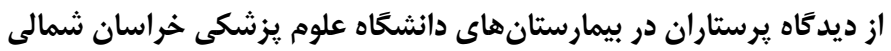

\begin{tabular}{|c|c|c|c|c|c|c|c|c|c|c|c|c|c|c|}
\hline \multicolumn{2}{|c|}{ ترس از عوامل } & \multicolumn{2}{|c|}{ عز به فامل مربوط درايند } & \multicolumn{2}{|c|}{ عواقب گزارش از } & \multicolumn{2}{|c|}{ عوامل مربوط } & \multicolumn{2}{|c|}{ عوامل مربوط برستار } & \multicolumn{2}{|c|}{ دارويى بخش هاى } & \multicolumn{2}{|c|}{ خطاهاى } & \multirow{2}{*}{ شتغيرهاى } \\
\hline$\frac{\mathbf{p}}{. \cdots 1}$ & $\frac{\mathbf{r}}{.1 / 17}$ & $\frac{\mathbf{p}}{. \cdots 1}$ & $\frac{\mathbf{r}}{\%: \varepsilon 0}$ & $\frac{\mathbf{p}}{. / .1}$ & $\frac{\mathbf{r}}{-0 / . \cdot r}$ & $\frac{\mathbf{p}}{. . .1}$ & $\frac{\mathbf{r}}{-\odot / \mu_{\varepsilon}}$ & $\frac{\mathbf{p}}{. \cdots 1}$ & $\frac{\mathbf{r}}{. / .1 r}$ & $\frac{\mathbf{p}}{. \cdots 1}$ & $\frac{\mathbf{r}}{-\cdot / \cdot \cdot \Lambda}$ & $\frac{\mathbf{p}}{.1 \% \varepsilon_{0}}$ & $\frac{\mathbf{r}}{. / .1}$ & \\
\hline 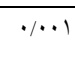 & $-\cdot / \cdot r$ &.+ .1 & $-0 / 1 \wedge 1$ & 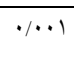 &.$- / \cdot 1 \varepsilon$ & $\cdot \cdot \cdot 1$ & 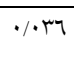 & 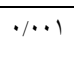 & $-. / 1 / 1$ & 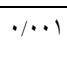 & $\% \cdot .7$ & $\cdots \cdot \cdot$ & $* \cdot \cdot 1$ & تحصيلات \\
\hline$\times, . .1$ & $1 \% \times 9$ & 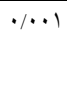 & $-\cdot / \cdot v v$ & $\% . .1$ & $-\cdot / \cdot \varepsilon \varepsilon$ & 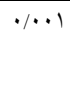 & $-0 /<\varepsilon 9$ & $\cdots, \cdot 1$ & $\% \pi r$ & 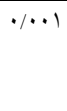 &.$- / .0 r$ & $1 / .79$ & $\% \cdot .1$ & سابقه كار \\
\hline 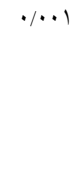 & $-0 / 4 r$ & $* . .1$ & $\cdots / \cdot 1$ & $\% . .1$ & $-0 / .07$ & 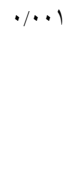 & $\| \Gamma V$ & $\cdots, .1$ & $\% / 19$ & $\%$ & $-* / \cdot \varepsilon \varepsilon$ & $\because \vee v v$ & $\cdots, \cdot 1$ & سابقه كار \\
\hline
\end{tabular}

عوامل مربوط به بخش، ترس از عواقب گزارشدهى،

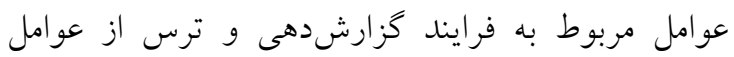
مديريتى رابطه معنى دارى وجود دارد (جدول شماره ب).
آزمون ويلكاكسون مستقل نشان داد كه بين متغيرهاى جمعيت شناختى از جمله جنسيت، كَذراندن دوره

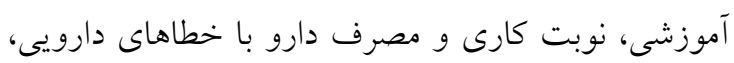
يروتكلهاى دارويى بخش، عوامل مربوط به يرستار،

جدول شماره سّ: ارتباط بين متغيرهاى كيفى جمعيتشناختى با خطاهاى دارويى، موانع كزارش دهارى و و عوامل مؤثر بر بروز خطاهاى دارويى

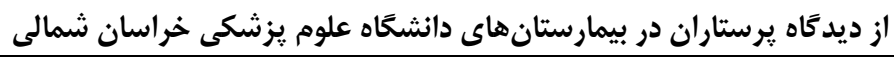

\begin{tabular}{|c|c|c|c|c|c|c|c|c|c|c|c|c|c|c|}
\hline \multirow{3}{*}{\multicolumn{2}{|c|}{ مد عروس امل }} & \multirow{2}{*}{\multicolumn{2}{|c|}{ عوامل فرايند }} & \multirow{2}{*}{\multicolumn{2}{|c|}{ تزارش از عواقب }} & \multirow{2}{*}{\multicolumn{2}{|c|}{ عوامل مربوط }} & \multirow{2}{*}{\multicolumn{2}{|c|}{ عوامل مربوط برستار }} & \multirow{2}{*}{\multicolumn{2}{|c|}{ دارويى بخش هاى }} & \multirow{2}{*}{\multicolumn{2}{|c|}{ خطاهاى }} & \multirow{3}{*}{ شتغير هاى } \\
\hline & & & & & & & & & & & & & & \\
\hline & & دهى & گزار & & & & & & & & & & & \\
\hline $\mathrm{p}$ & $\mathrm{z}$ & $\mathrm{p}$ & $\mathrm{Z}$ & $\mathrm{p}$ & $\mathrm{Z}$ & $\mathrm{p}$ & $\mathrm{Z}$ & $\mathrm{p}$ & $\mathrm{Z}$ & $\mathrm{p}$ & $\mathrm{Z}$ & $\mathrm{p}$ & $\mathrm{Z}$ & جنس \\
\hline$\%, \cdot 1$ & -1. & $\cdot / . .1$ & -1. & $\cdot / . .1$ & -1. & 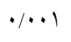 & -1. & $\cdot / . .1$ & -9 & 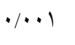 & -9 & $\cdot / . .1$ & -1. & \\
\hline$\%$ & -1. & $\cdot / . .1$ & -1. &.. .1 & -1. & $\cdots \cdot$ & -1. & 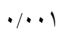 & -1. & 1..1 & $-1 . \% \cdot 1$ & $1 . .1$ & -9 & نوبت كارى \\
\hline 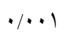 & -1. & $\cdot / . .1$ & -1. &.. .1 & -1. & $\% \cdot \cdot 1$ & -1. & $\cdot / \cdot 1$ & $1 \% \bullet 1$ & 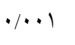 & $-1 . / . r$ & $\cdot / . .1$ & -9 & كذراندن دوره \\
\hline & & & & & & & & & & & & & & ى آموزشى \\
\hline 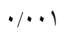 & -1. &.. .1 & -9 & $\cdot / . .1$ & -1.1 .9 & $\%$ & -1. & $\cdot / . .1$ & -9 & 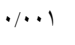 & -9 & . $/ .1$ & -1. & مصرف دارو \\
\hline
\end{tabular}


مربوط به بخش، ترس از عواقب گزارش دهى و عوامل

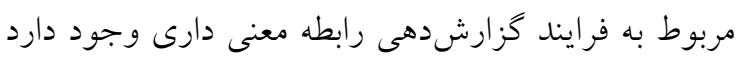

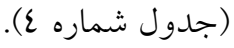

همجنين آزمون كروسكال واليس نشان داد كه نوع استخدام و بخش محل كار با خطاهاى دارويى، يروتكل هاى دارويى بخش، عوامل مربوط به يرستار، عوامل

جدول شماره ع: ارتباط بين متغيرهاى كيفى جمعيتشناختى با خطاهاى دارويى، موانع تزارش دارهى و عوامل مؤثر بران بر بروز خطاهاى دارويى

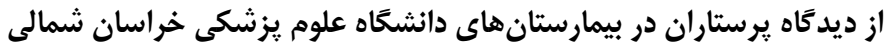

\begin{tabular}{|c|c|c|c|c|c|c|c|c|c|c|c|c|c|c|}
\hline \multirow{2}{*}{\multicolumn{2}{|c|}{ ترس از عوامل }} & \multirow{2}{*}{\multicolumn{2}{|c|}{ 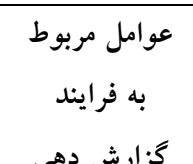 }} & \multirow{2}{*}{\multicolumn{2}{|c|}{ ترس از عوارش دهى }} & \multirow{2}{*}{\multicolumn{2}{|c|}{ عوامل مربوط به }} & \multirow{2}{*}{\multicolumn{2}{|c|}{ عوامل مربوط به }} & \multirow{2}{*}{\multicolumn{2}{|c|}{ دارويى بخشل هاى }} & \multirow{2}{*}{\multicolumn{2}{|c|}{ خطاهاى }} & \multirow{2}{*}{ متغيرهاى } \\
\hline & & & & & & & & & & & & & & \\
\hline $\mathrm{p}$ & $\begin{array}{c}\text { Chi- } \\
\text { square }\end{array}$ & $\mathrm{p}$ & $\begin{array}{c}\text { Chi- } \\
\text { square }\end{array}$ & $\mathrm{p}$ & $\begin{array}{c}\text { Chi- } \\
\text { square }\end{array}$ & $\mathrm{p}$ & $\begin{array}{c}\text { Chi- } \\
\text { square }\end{array}$ & $\mathrm{p}$ & $\begin{array}{c}\text { Chi- } \\
\text { square }\end{array}$ & $\mathrm{p}$ & $\begin{array}{c}\text { Chi- } \\
\text { square }\end{array}$ & $\mathrm{p}$ & $\begin{array}{c}\text { Chi- } \\
\text { square }\end{array}$ & \\
\hline.$/ .1$ & $r$ & $\% / \cdots 1$ & $r$ & $\% \cdot \cdot 1$ & $r$ &.$/ \cdot 1$ & $r$ & $\% \cdots 1$ & $\varepsilon$ &.$/ .99$ & $\pi$ &.$/ .1$ & $r$ & نوع استخدام \\
\hline.$/ 7 \varepsilon$ & ir &.$/ . \cdot 1$ & r &.$/ . .1$ & r &.$\cdots 1$ & v & $\% \varepsilon$ & $1 \varepsilon$ &.$/ . .1$ & ro & $\cdot / \cdot \cdot 1$ & 7 & بخش محل كار \\
\hline
\end{tabular}

آمريكايى سرعت انفوزيون اشتباه و دادن دارو بدون

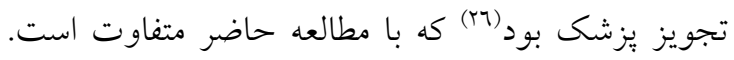
دارو رايجترين كالاى درمانى مصرفى در واحدهاى دارى ارائه

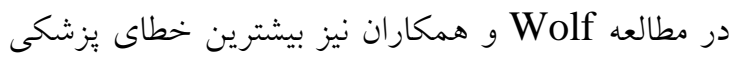

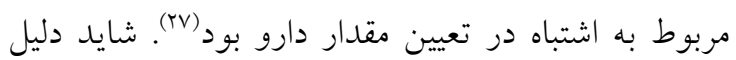

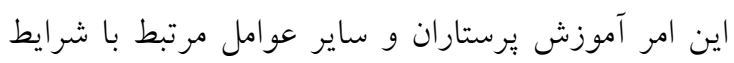
روانى برستاران باشد. هم:جنين در مطالعه حاضر كمترين فراوانى اشتباهات دارويى مربوط به تزريق داروى وريدى بـى بهري به صورت عضلانى با 10 مرتبه تكرار بود، كه مؤيد يافته هاى مطالعه ميرزايى و همكاران است (10). طبق نتايج

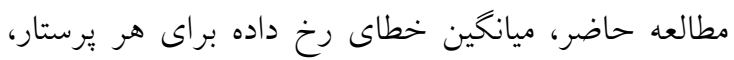
9/7 در سه ماهه كذشته بوده است. در مطالعه جولايى و همكاران، ميانخين وقوع خطاى دارويى 19/0 مورد بودهد

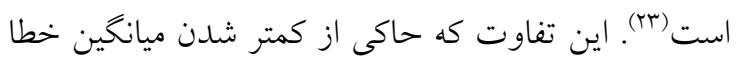

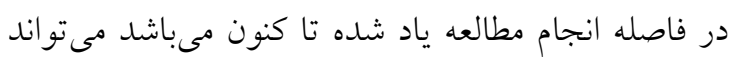
به دليل بهتر شدن سياستهاى كزاردش دهى و همجنِين تفاوت در جامعه مورد مطالعه است، جرا كه مطالعه

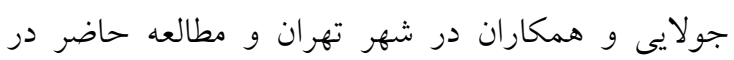

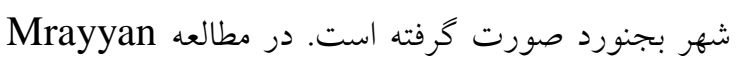

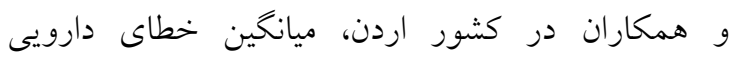

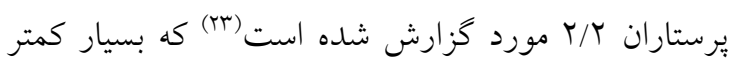
از ميانخين خطا در سالهاى مختلف در كشور مىباشد.

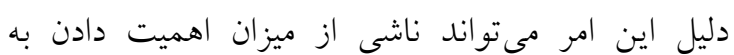

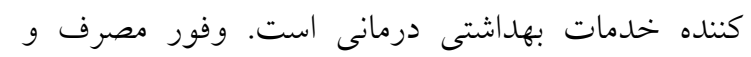

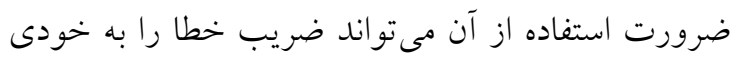

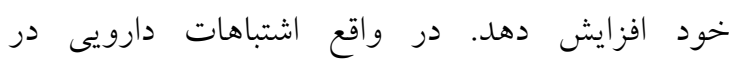

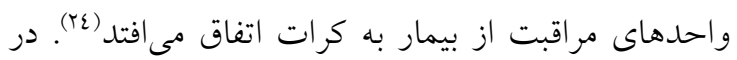

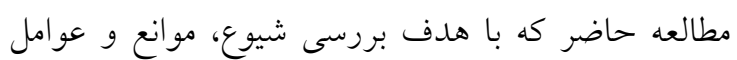
مؤثر بر بروز خطاهاى دارويى از ديدكاه يرستاران در

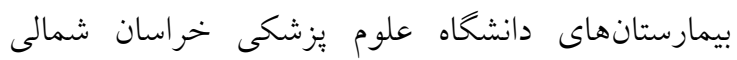

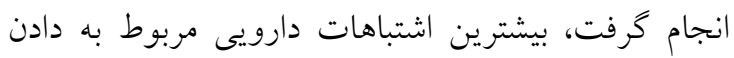

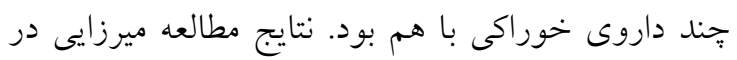

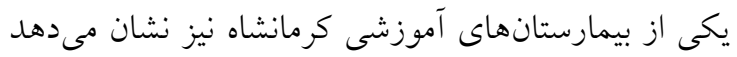
دادن جند داروى خوراكى به طور همزمان و دادن دارو

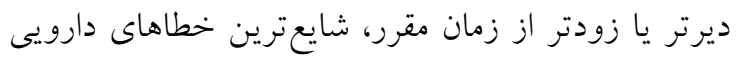

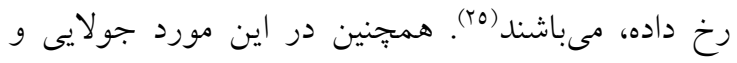

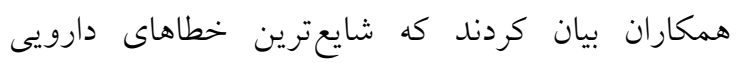

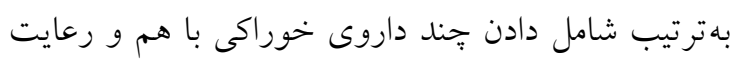

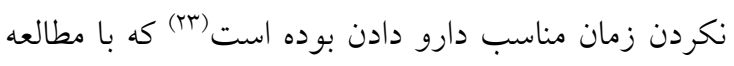

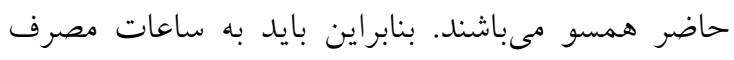

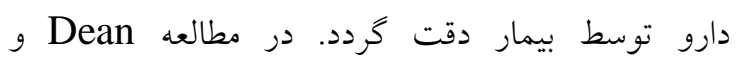

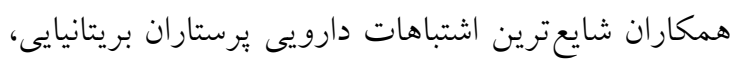

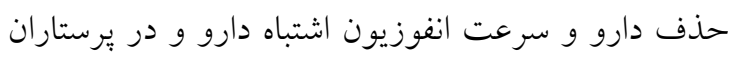


بررسى ع •ا يرونده جهت بررسى علل خطاهاى دارويى

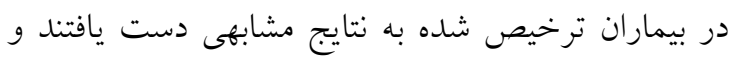

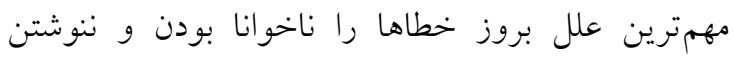

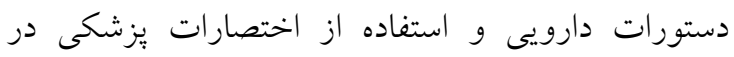
بروندهها دانستند ("r) كه با مطالعهى حاضر مطابقت دارد.

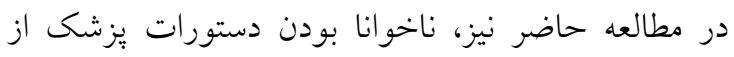

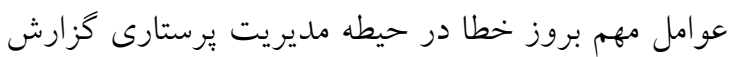
در راستاى نتايج مطالعه در رابطه با علل موانع كزارشدهى، در مطالعه كوهستانى نيز بيشترين ميانگين

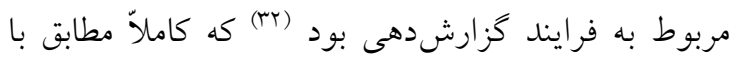
يُزوهش حاضر است در حالى كه مطالعه حيدرى حاكى از

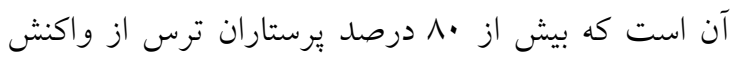

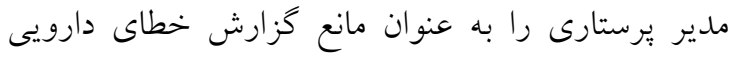

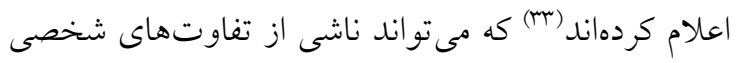

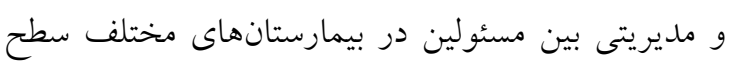

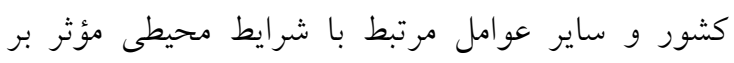

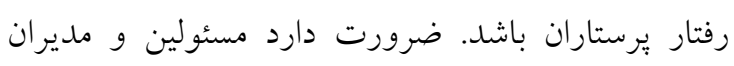

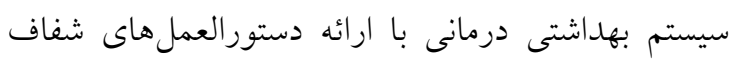

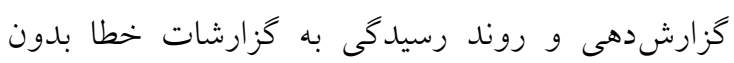

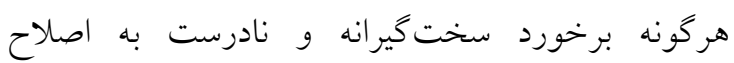

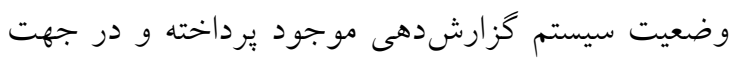
تشويق مؤثرتر يرسنل سيستم بهداشتى درمانى به ارائه كزارش صحيح تلاش نمايند.

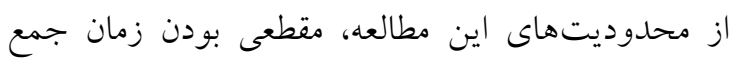

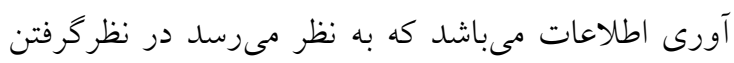
بازه زمانى طولانىتر منجر به نتايج يربارترى خواهد شد.

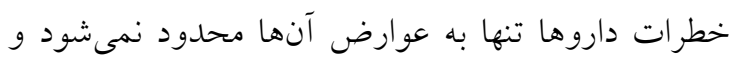
بسيارى از مشكلات مىتوانند در طى فرايندهاى تجويز دارو، توزيع و اجراى دستورات دارويى رخ دهند. بنابراين با توجه به بررسىهاى صورت كرفته مبنى بر بروز

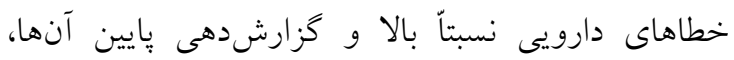

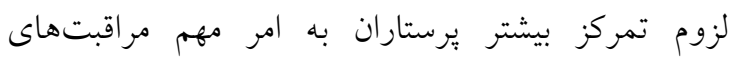

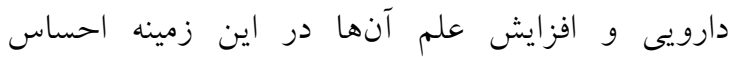

خطاهاى دارويى، سياستهاى بيمارستانها در امر آموزش

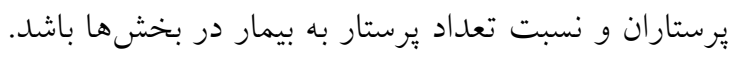

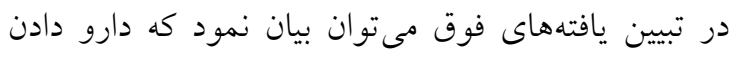

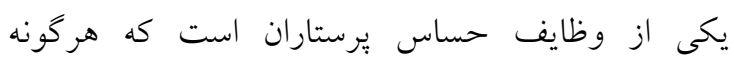

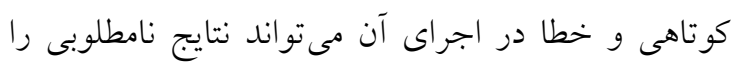
براى بيمار به دنبال داشته باشد. بنابراين يا توجه به اينكه

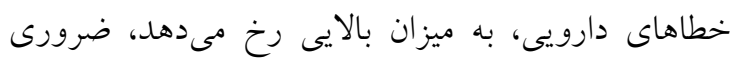

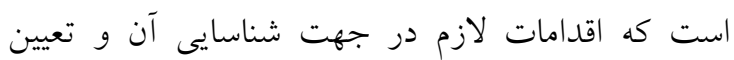

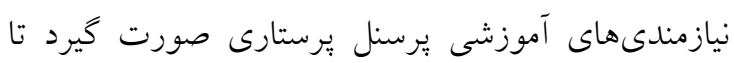
بتوان اين خطاهاى دارويى را به كمترين ميزان آن رساند.

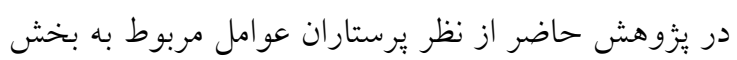
به عنوان مهمترين عوامل وقوع خطاهاى دارويى مطرح

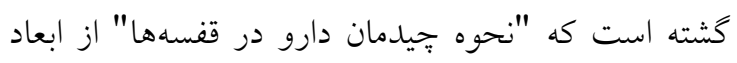
اين حيطه مىباشد. در مطالعه محمدنزاد و همكاران، شايع دئه

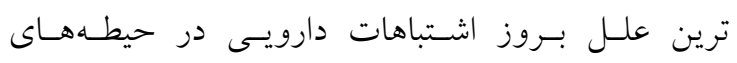
سازمانى و انسانى، كمبود تعداد برستار نسبت به تعداد

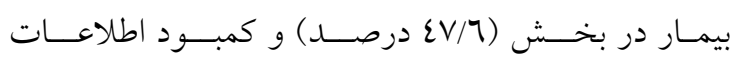

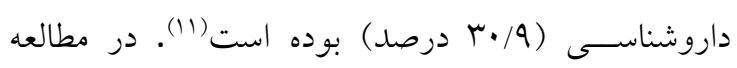
Haw

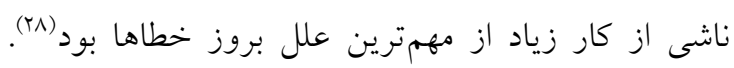
Hicks عوامل مهم بروز خطاهاى دارويى در واحدهاى مراقبت دادئ

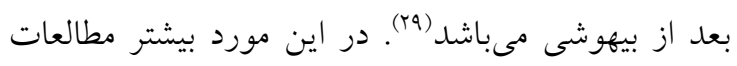

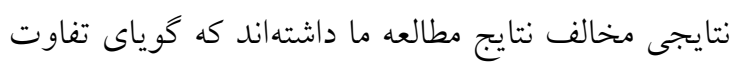

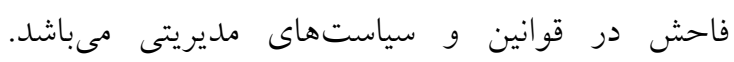

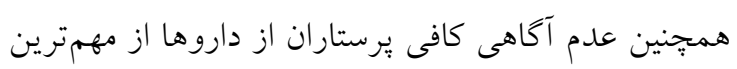
علل بروز خطاهاى دارويى كزارش شد كه اهمئ اهميت توجه

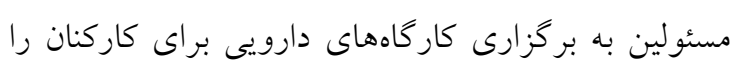

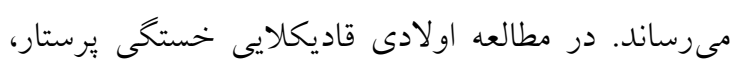

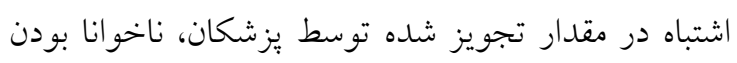

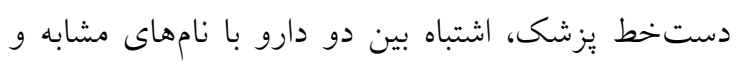

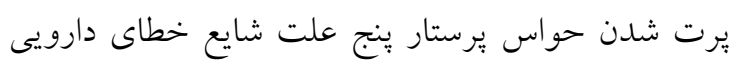

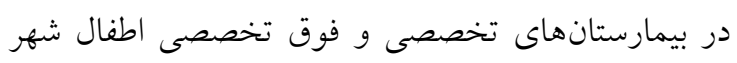

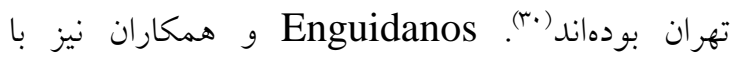




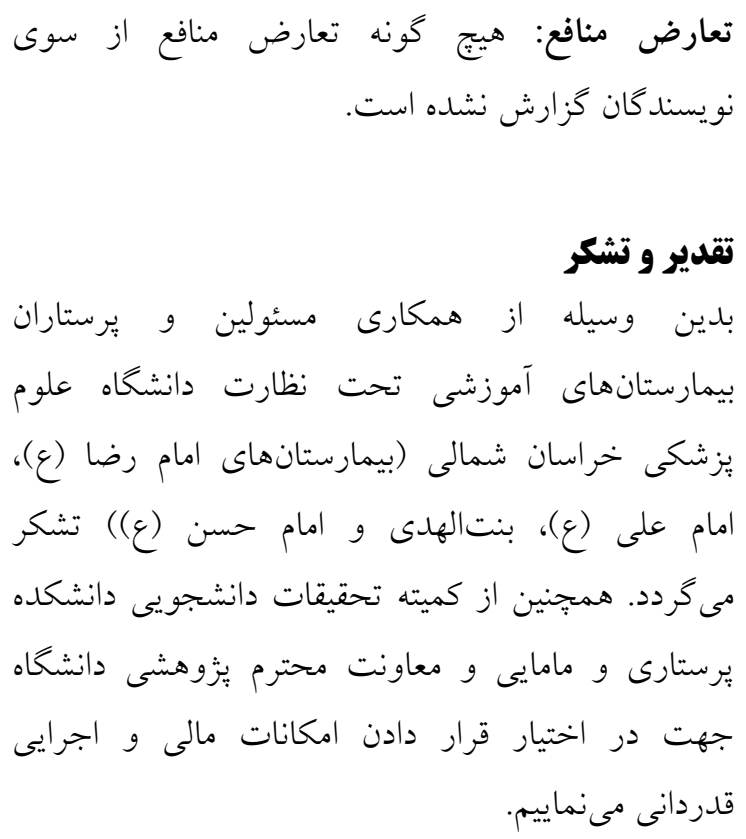

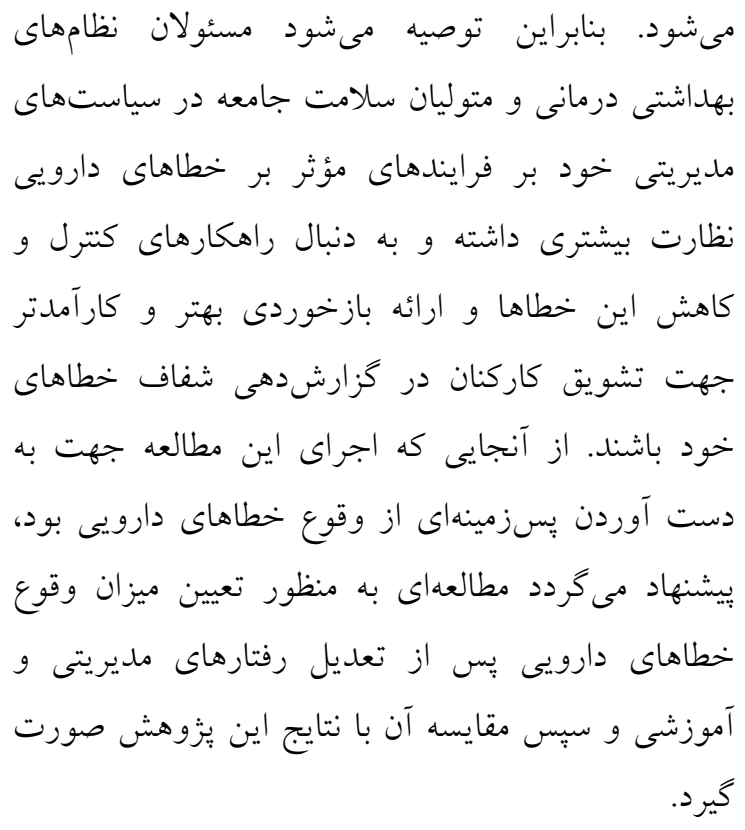

\section{References}

1. Mayo AM, Duncan D. Nurse perceptions of medication errors: what we need to know for patient safety. J Nurs Care Qual. 2004;19(3):209-17.

2. Benner P, Sheets V, Uris P, Malloch K, Schwed K, Jamison D. Individual, practice and system causes of errors in nursing: a taxonomy. JONA: The Journal of Nursing Administration. 2002;32(10):509-23.

3. Guchelaar HJ, Colen HB, Kalmeijer MD, Hudson PT, Teepe-Twiss IM. Medication errors. Drugs. 2005;65(13):1735-46.

4. Fontan JE, Maneglier V, Nguyen VX, Brion F, Loirat C. Medication errors in hospital: computerized unit dose drug dispensing system versus ward stock distribution system. Pharm World Sci. 2003;25(3):112-7.

5. Cassiani SH. Patient safety and the paradox in medication use. Rev bras enferm. 2005;58(1):959.

6. Hosseinzadeh M, Ezate Aghajari P, Mahdavi N. Reasons of nurses' medication errors and persepectives of nurses on barriers of error reporting. Journal of hayat. 2012;18(2):66-75. [Persian]

7. Souzani A, Bagheri H, Pourheydari M. Survey nurse's view about factors affects medication errors in different care units of Imam Hossein hospital in Shahroud. Knowledge And Health. 2007;2(3):8-13. [Persian]

8. Jolaee S, Shali M, Haghani $\mathrm{H}$. The relationship between incidence of medication errors and nurse's professional commitment. Medical Ethics Journal. 2014;8(28):101-19. [Persian]

9. Nikpeyma N, Gholamnejad H. Reasons for medication errors in nurses' veiws. Advances in Nursing \& Midwifery. 2009;19(64):16-24. [Persian]

10. Mohammad Nejad I, Hojjati H, Sharifniya SH, Ehsani SR. Evaluation of medication error in nursing students in four educational hospitals in Tehran. Iranian Journal of Medical Ethics and History of Medicine. 2010;3(1):60-9.

11. MohammadNejad E, Ehsani S, Salari A, Sajjadi A, HajiesmaeelPour A. Refusal in Reporting Medication Errors from the Perspective of Nurses in Emergency Ward. Journal of Research Development in Nursing \& Midwifery. 2013;10(1):61-8. [Persian]

12. Mardani Hamooleh M, Shahraki Vahed A. The obstacles in reporting nursing error: a nurses' perspective. Iranian Journal of Medical Ethics and History of Medicine. 2009;2(4):55-62. [Persian] 
13. Bagherieh F, Hashemlo L, Baghaei R, Feizi A, Shams SH. Frequency of medication errors and its reporting according to self-report by nurses in hospitals of Khoy city. The Journal of Urmia Nursing and Midwifery Faculty. 2012;10(5):721-6. [Persian]

14. Anderson P, Townsend T. Medication errors: Don't let them happen to you. American Nurse Today. 2010;5(3):23-8.

15. Bailey CG, Engel BS, Luescher JN, Taylor ML. Medication errors in relation to education \& medication errors in relation to years of nursing experience. J Nurs Res. 2008;3:1-4.

16. Valizadeh F, Ghasemi SF, Nagafi SS, Delfan B, Mohsenzadeh A. Errors in medication orders and the nursing staff's reports in medical notes of children. Iranian Journal of Pediatrics. 2008;18(1):33-40. [Persian]

17. Zare ZG, Purfarzad Z, Adib-Hajbaghery M. Medication management skills of nursing students: Comparing the students and their instructors' evaluation in two universities. Nurs Midwifery Stud. 2013;1(3):139-45. [Persian]

18. Harding L, Petrick T. Nursing student medication errors: a retrospective review. J Nurs Educ. 2008;47(1):43-7.

19. Stratton KM, Blegen MA, Pepper G, Vaughn T. Reporting of medication errors by pediatric nurses. J Pediat Nurs. 2004;19(6):385-92.

20. Beydokhti TB, Mohamadpour A, Shabab S, Nakhaee H. Cause of occurence and Barriers of Report of Medication Errors among Nursing Personnel of Gonabad Hospitals. Horizon. 2014 Mar;19(5):41-7. [Persian]

21. Kawamura H. The approaches to factors which cause medication error from the analyses of many near-miss cases related to intravenous medication which nurses experienced. Gan to kagaku ryoho. Cancer \& chemotherapy. 2001;28(3):304-9.

22. Hashemi F, Nikbakht NA, Asghari F. Nurses perceived worries from error disclosure: A qualitative study. Iranian Journal of Nursing Research. 2011;6(20):30-43. [Persian]

23. JolaieS HF, Peyravi H, Haqqani H. Investigated the occurrence and reporting of medication errors in nursing and its relationship with working conditions in the hospitals of Iran University of Medical Sciences. Journal of Medical Ethics and History. 2009;3(1):65-76. [Persian]

24. Mrayyan MT, Shishani K, AL-Faouri IB. Rate, causes and reporting of medication errors in Jordan: nurses' perspectives. Journal of nursing management. 2007;15(6):659-70.

25. Mirzaei M, Khatony A, Faramani RS, Sepahvand E. Prevalence, Types of Medication errors and Barriers to Reporting Errors by Nurses in an Educational Hospital in Kermanshah. Hayat. 2013 J;19(3):1-10. [Persian]

26. Dean BS, Allan EL, Barber ND, Barker KN. Comparison of medication errors in an American and a British hospital. Am J Health Syst Pharm. 1995;52(22):2543-9.

27. Wolf ZR, Hicks R, Serembus JF. Characteristics of medication errors made by students during the administration phase: a descriptive study. J Prof Nurs. 2006;22(1):39-51.

28. Haw CM, Dickens G, Stubbs J. A review of medication administration errors reported in a large psychiatric hospital in the United Kingdom. Psychiatric Services. 2005;56(12):1610-3.

29. Hicks RW, Becker SC, Krenzischeck D, Beyea SC. Medication errors in the PACU: a secondary analysis of MEDMARX findings. Journal of perianesthesia nursing. 2004;19(1):18-28.

30. Oladi Ghadikalaee R, Ravaghi H, Hesam S. Study Of Nurses' Perceptions On Medication Errors In Pediatric Hospitals In Tehran, Iran. Journal of Payavard Salamat. 2015;9(3):315-28. [Persian]

31. Enguidanos SM, Brumley RD. Risk of medication errors at hospital discharge and barriers to problem resolution. Home Health Care Serv Q. 2005;24(1-2):123-35.

32. Kohestani H. Investigation medication errors of nursing students in Cardiac. Iranian Journal of Forensic Medicine. 2008;13(4):249-55. [Persian]

33. Heydari H, Kamran A, Pirzadeh A. Assessment of Nurses'perceived Barriers and Behaviors to Reporting Medication Errors in Hospitals of Lorestan University of Medical Sciences, Iran. Health System Research. 2012;8(5):806-13. [Persian] 